\title{
The issues of oppressed groups' access to collectively managed resources: an empirical analysis
}

\author{
Bhubaneswor Dhakal ${ }^{1}$
}

\begin{abstract}
Oppressed groups' problem in collective management of resource is examined in the case of Kami's (Blacksmith) access to charcoal in community forests in Nepal. A field survey shows that almost a half forest user groups have excluded the Kami for charcoal collection. In the government policies, rights of households with special needs are not clearly defined and protected. In an econometric analysis of the user groups, this study identified forest size, group size, intensive external support and groups' meeting frequency are the factors determining the charcoal distribution in community forests.
\end{abstract}

Key words: Community forest, exclusion, livelihood, protected rights, and special need group

$\mathbf{T}$ he collective approach for managing common pool resource valuable for livelihood and environment is evolving in many developing countries. Side by side the freedoms and opportunities of the resource dependent occupational and oppressed groups are becoming increasingly recognised. However, the problems of socially oppressed and special need groups in this politico-ecological complex approach are little known. To enhance the knowledge this study examines the change in access to charcoal for Kami (Blacksmith) after the introduction of community forestry programme in Nepal.

The Kami is traditionally a forest dependent occupational group (Hobley, 1996). Historically this ethnic group has played a key role in social civilization and sustaining small tool based mountain farming. This group makes and repairs agricultural tools, ornaments and other utensils in charcoal and local technology based workshops. The market supply and alternative maintenance service of the equipment, tools and other utensils are still unavailable in many parts of the country where the Kami provides a low cost services working in traditional workshops. Some mountain communities could have yet remained in nomadic life if the service had not been provided widely in the country that has been fragmented by rocky-mountains, high hills and high current rivers originated from glaciers.

Though the Kami has provided a vital service to the society, this is a socially oppressed (so called an untouchable caste), and economically disadvantaged group in Nepal. Table 1: shows some socio-economic attributes of the Dalit group in Nepal. The Kami belongs to the Hill Dalits' (oppressed) group and most of the households have critical poverty. Their

Table 1 : The Dalit group's comparative socio-economic status

\begin{tabular}{lccccccccc}
\hline \multicolumn{1}{c}{$\begin{array}{c}\text { Human } \\
\text { Development } \\
\text { indicators }\end{array}$} & $\begin{array}{c}\text { Nepal } \\
\text { (average) }\end{array}$ & Bahun & Chhretri & Newar & $\begin{array}{c}\text { Hill } \\
\text { Janjati }\end{array}$ & $\begin{array}{c}\text { Terrai } \\
\text { ethnicity }\end{array}$ & $\begin{array}{c}\text { Hill } \\
\text { Dalit }\end{array}$ & Muslim & Others \\
\hline $\begin{array}{l}\text { Life } \\
\begin{array}{l}\text { Expectancy } \\
\text { (years) }\end{array}\end{array}$ & 55 & 61 & 56 & 62 & 53 & 58 & $\mathbf{5 0}$ & 49 & 54 \\
$\begin{array}{l}\text { Adult Literacy } \\
(\%)\end{array}$ & 37 & 58 & 42 & 55 & 35 & 28 & $\mathbf{2 4}$ & 22 & 28 \\
$\begin{array}{l}\text { Mean years } \\
\text { Schooling }\end{array}$ & 2 & 5 & 3 & 4 & 2 & 2 & $\mathbf{1}$ & 1 & 2 \\
$\begin{array}{l}\text { Per Capita } \\
\text { Income (NRs) }\end{array}$ & 7673 & 9921 & 7744 & 11953 & 6607 & 6911 & $\mathbf{4 9 4 0}$ & 6336 & 7312 \\
\hline
\end{tabular}

(Source: NPC, 2003)

1 Ph.D Scholar Lincoln University, New Zealand, Email: bhubaneswordhakal@yahoo.co.nz 
representations in political power and the government services are far smaller in comparison to their 3.9 percent of total population (NPC, 2003).

As a poor occupational group the Kami needs regular supply of charcoal from community forests. However, there is little study done about the Kami specifically for the charcoal distribution problem in Nepal. Therefore this study could make a contribution to both theory and policy.

\section{The institutional theories and oppressed groups}

Since the community forestry development is an institutional change, the charcoal distribution problem could be explained better by distributive institutional theories. These frameworks are reviewed in this section.

\section{Access to and control over resources}

The property rights are to be assigned to an appropriate common pool resource when societies face scarcity. Bromley (1989) stated the property rights are socially recognized or legally enforced power to conserve, use and control over valuable object or worthy creation and exclude potential claimants. The right enable some and constrains others to access benefit of particular property or wealth. This right assignment is an act of distributing wealth that determines secured access to income for survival and enjoyment. Access, on the other hand, defines as getting resource by bundles and webs of means such as material, cultural and politicoeconomic (property rights) powers and personality influences (Ribot and Peluso, 2003). This means access to resource is largely a matter of individual's capability when property rights are not specified.

Scholars have propounded many principles and theories of property rights for secure access on a resource. Social justice is a commonly agreed distributive principle. Since the social justice is a socially defined reality (Young, 1990), then how to define social justice for assigning property rights is a debatable issue. Dobson (1998), however, argued need, desert and entitlement are justifiable distributive principles. The need principle is based on Karl Marx thesis that the resources should be distributed according to need and according to ability. The desert principles posit that the individual should be provided or honoured for what he or she gave to the society.
The entitlement principle explains that the individual entitle to get the thing that the person has the relation on it in the original condition. Rawls (1971) argue a greater benefit of the least advantaged parties or individuals is a fair practice and a social justice. Bromley (1989) also listed many other theories: the first occupancy, the labour theory, the utility theory, the political theory and the moral enhancement.

Recently, the rights of traditionally resource dependent or aborigine people are becoming valued for resolving distributive conflicts and human right violation (Vogt, 1998). Ways of lifestyles, social behaviours and cultures of ethnic people have evolved and are attached to local resources. Accessing the local resource is their human right to maintain the lifestyles and enjoy the cultures. Groups with secure property right can have secure access and greater say about the resource. For example, Maori some how lagged behind participating mainstream socio-political opportunities but have enjoyed access to natural resources greater than other New Zealanders. Contemporary aborigines of Canada and Australia have little say and less control over natural resources (Challen, 2000; Vogt, 1998) and are more vulnerable. The secure access is important to disadvantaged groups to cope with extreme situations. The freedoms and hedging opportunities of people should not be harmed while changing institution for benefiting other people.

\section{Distributive problems and determinants of common property}

Duncan (1996) stated as long as poor people live in their traditional communities their poor social (including community norms and class structures), human, physical, financial and natural capitals transfer from one generation to other and thus they suffer from oppression and poverty persistently. On the other hand, Kothari (2003) explained the poor capitals reinforce the probability of deprived people to stay in the community. Even if they migrate out, insufficiency of hedging capitals make them more likely to suffer. In this case they could be better off if local opportunities were increased to minimise their universal suffering.

Desirable distributive institutional arrangements are possible to achieve purposeful actions when the state authority enjoys superior bargaining position and acts benevolently in institutional changing processes (Weimer, 1997). However, gender case based studies 
identified that government agencies make aggregative policies consciously or unconsciously to resolve their target problems, and ignore circumstances of oppressed or special need groups. These case-blind policies benefit privileged groups and marginalize special need people (Kabeer and Subrahmanian, 1996). These biased policies rather force the oppressed people to work in the interest of the privileged groups (Young, 1990).

Studies indicated that intra community factors also determine distributive outcomes of a common property where the property rights are not clearly defined. These factors include leadership attributes, local conditions, beneficiaries' capability (capital) and community size. The demand of users and the size of the resources are other determinants for benefit distribution (Adhikary et al, 2004; Vedeld, 2000; Janvry et al, 1998).

\section{Policies review}

Historically the charcoal collection by the Kami was free in the local forests based on the understanding that the Kamis service benefits communities (Mahat et al, 1987). The forest Act 1993 has given some rights to local user groups under the condition that the group should develop the forest management rules within given government policies and approved it by the state agency (Hobley, 1996). The forest acts and bylaws stated to grant local forest use rights irrespective of political boundary but it has not specified the special provision of need based groups like the Kami.

The government has agreed and signed the declaration The Rio Declaration on Environment and Development. The principle 23 of the declaration state that 'the environment and natural resources of people under oppression, domination and occupation shall be protected'. As per action plan stated in Agenda 21 , the government has formulated and revised many policies and programmes of natural resource management. However, there is no specified action plan or stated conditions to address the charcoal supply problem.

Above theories support the need of assigning special right to oppressed groups like the Kami but the government policies are found silent on this issue. Based on the literature review a research model explaining the access to charcoal is formulated as follows.

\section{The conceptual model}

The Kami household could manage livelihood from various opportunities: private property, community property, cash assets and income from working outside the community. The Kami households with little capital therefore could be better off being involved in the family occupation when there are little other better prospects.

As an oppressed group, and one with legally no well defined and protected rights, the Kami could lose access to charcoal in some community forests. That exclusion could be determined by some factors in their communities. For example, Adhikary et al (2004) stated that the distributive problem in common property arises more in heterogeneity groups that consist diversified interests and power. The larger groups could have better heterogeneity, more difficult to communicate, and less cooperation. Thus, the larger group is less likely to distribute the charcoal and, thus group size could posses negative relationship. Similarly, the forests with larger forestland may have more resource. In resource scarcity condition, the likelihood of providing charcoal could be negative in small forests.

Vedeld (2000) found that the leadership is more important determinant for benefit distribution of collective action than the heterogeneity. The high power groups become more able to influence on the decision or to reap the benefits of common (Adhikary et al, 2004). The concerns and voices of minority and oppressed groups could easily overhear in these collective complexities. Brahmin, Chbetri and Newar are influential and well off ethnic groups in the society (Bista, 1991). Therefore, the likelihood of charcoal distribution is expected to be negative in the groups led by these dominating ethnic groups. The chairperson working longer period could have enough time to listen many issues of members and to improve the weaknesses. The charcoal providing probability could be higher in the user groups with chairperson having longer experience.

The users in executive committee hold greater level of power to make decision on many issues and agenda setting for general assemblies. Participation of an individual or groups in decision making provides greater opportunities to put their concern in the agenda of decision-making. If an executive committee has a representative of the Kami there could be a greater chance that the charcoal issue are 
addressed. The female than that of male has dependency in forests (Agrawal, 2001) and other local services. As a dependent on local resource and services, the female could care more to charcoal supply issue than counterpart. Therefore it is expected that the higher percentage of female represented in executive committee the higher the probability of charcoal distribution.

In quality aspect Ghate (2003) found better institutions of forest user groups supported by NonGovernmental Organisations (NGOs) than the government agency in India. The non-government development workers could give more time in community and influence on user group decision to distribute the charcoal for the occupational ethnicity group. Thus the chance of distributing charcoal in intensive project supported groups could be positive. Similarly, if user group meeting are held more frequently many issues including charcoal distribution are likely to be discussed. Thus the probability of getting the charcoal could be positive for higher number of meetings.

Based on the above hypotheses the charcoal supply model is formulated as:

Charcoal $=f$ (AREA, HHNO, HIGHSUPRT, MFREQ, DETHNIC, WOMEN, REPRES) .....(1)

The definitions of the variables are as followings.

CHARCOAL $=$ Whether a Kami gets charcoal from a community forest (if yes 1 , no 0 )

LOGAREA $=$ Logarithm of forest area (hectare)

HHNO $=$ household numbers in the user group

HHSQ $\quad=$ Squared of household numbers in the group

HIGHSUPRT $=$ Intensive support district (project staff involved for user group support 1 , otherwise 0 )

MFREQ $=$ Executive committee meeting frequencies number in a year

DETHNIC $=$ Chairperson of the executive committee is dominating casts (if Brahaman, Chhreti and Newar is 1 , otherwise 0)

WOMEN $=$ Number of female representative in user groups' executive committee

REPRES = Oppressed group representative (Kami or other similar ethnic group) in executive committee (if yes 1 , otherwise 0 )

EXPR $=$ Period of chairperson holding the executive power (experience year)

The equation (1) is a model for empirical analysis. The data and the method of testing the model are discussed in the following section.

\section{Data and Methods}

It is costly to collect empirical data from large sample introduced in common property. Therefore most of the studies in common property problems are done with smaller samples (Agrawal, 2002). With the cost and time constraints, to analyse the charcoal distribution problem, a survey was completed in 64 forest user groups in three mid hills districts (Kavre, Dolakha and Nuwakot) of Nepal. These districts had some level of differences for institution building of district forest offices and user groups. Dolakha and Kavre districts have intensive supports of some donor-funded projects. Nuwakot district has little external support. On an average 21 user groups were surveyed from each district representing various age group, type of forests, ethnic groups, size of households and size of forest areas. The user group representatives were asked about whether the group has Kami workshops and how they had managed their charcoal need. The Kami workshops were reported only in 40 user groups. The missing data for number of female representation in executive committee was collected from national database. The Logit model is the most appropriate method to analyse binary (yes or no) qualitative dependent variable. It estimates good results even in small samples (Long, 1997).

\section{Results}

The community level data were analysed descriptively and econometrically. These results are presented below in separate sections.

\section{Descriptive results}

Out of 64 user groups surveyed about two-third of user groups have Kami workshops and demand for charcoal. The charcoal is not distributed among almost 50 percent groups. Kami workshops have been managed by begging or buying trees from rich households. Some of them dug up roots of trees felled for firewood. The other workshops had managed coal from markets. The respondents told 
that their workshop activities were decreased and that had made their life more difficult. Financial problem and availability of fuelwood in local market were the main problems to mange charcoal. In this field study, one user committee reported that Kami started using the charcoal leftover after burning dead body of human though it is culturally unacceptable. However, none- of the user groups reported closing of the iron workshop completely due to the problem of charcoal supply.

Table 2 explains descriptive statistics of the variables of regression analysis. The value of area is transformed in logarithmic form. The figures only in decimal value indicate that they are the dummy variables.

\section{Econometric results}

Table 3 depicts EVIEWS software outputs of logit analysis for the group level determinants. The model was passed through its essential econometrics attributes to explain the problem.

The signs of all variables are consistent with expectation. However, only the variables-
LOGAREA, HHNO, HHSQ, HIGHSUPRT and MFEQ are found significant at less than 10 percent and explained better for providing charcoal to the Kami. The variables with little explanatory power are deleted from the model to precise the efficiency of significant variables' coefficients.

The result shows probability of providing charcoal by a forest user group increases significantly log linearly with the size of forest area. There is no reference to compare the result. However, the result is logical in the sense that the larger size of forestlands generally consist more resources. The increase in household size had positive effect on providing the charcoal but found decreasing as the size of the group increases after certain size. The result for group size is some how consistent with the common property literatures that the increase in size affects the cooperation in common (Olson, 1965). Similarly the probability of charcoal providing increases with increase in the number of meeting frequencies in general. The frequent meetings could provide sufficient time for a committee to think and discuss on many important agenda including the charcoal supply. The groups with high frequency meeting therefore could have given attention on the charcoal supply.

Table 2 : Means and standard deviations of the variables

\begin{tabular}{lcccc}
\hline \multirow{2}{*}{ Variables } & \multicolumn{3}{c}{ Mean } & $\begin{array}{c}\text { Standard deviation } \\
\text { for all }\end{array}$ \\
\cline { 2 - 4 } & Dep $\mathbf{n} \mathbf{0}(\mathbf{n}=\mathbf{2 1})$ & Dep $=\mathbf{1}(\mathbf{n}=\mathbf{1 9})$ & Average of all & 0.39 \\
\hline LOGAREA & 1.75 & 2.06 & 1.89 & 130.55 \\
HHNO & 213.62 & 187.63 & 201.27 & 76422.52 \\
HHSQ & 73278.76 & 39279.95 & 57129.00 & 0.50 \\
HIGHSUPRT & 0.43 & 0.74 & 0.57 & 4.81 \\
MFREQ & 9.09 & 10.47 & 9.75 & 0.38 \\
DETHNIC & 0.86 & 0.79 & 0.82 & 2.33 \\
WOMEN & 2.33 & 2.95 & 2.62 & 0.47 \\
REPRES & 0.62 & 0.76 & 0.67 & \\
\hline
\end{tabular}

Table 3 : The Logit model for charcoal distribution

\begin{tabular}{|c|c|c|c|c|}
\hline Variables & Coefficient & Std. Error & z-Statistic & Prob. \\
\hline CONSTANT & -15.69 & 5.46 & -2.87 & 0 \\
\hline LOGAREA & 3.69 & 2.02 & 1.83 & 0.06 \\
\hline $\mathrm{HHNO}$ & 0.06 & 0.03 & 2.45 & 0.01 \\
\hline HHSQ & -0.01 & 0 & -2.52 & 0.01 \\
\hline HIGHSUPRT & 2.7 & 1.3 & 2.07 & 0.03 \\
\hline MFREQ & 0.23 & 0.11 & 1.98 & 0.05 \\
\hline Hosmer-Lemeso Statistic & $3.3(0.91)$ & \multicolumn{2}{|c|}{ Log likelihood } & -12.52 \\
\hline$(\mathrm{Ch}-\mathrm{Sq} 8)$ & & & & \\
\hline Prediction percent correct & 85 & \multirow{2}{*}{\multicolumn{2}{|c|}{$\begin{array}{l}\text { Restricted Log likelihood statistic } \\
\text { LR statistic }(\mathrm{df}=5)\end{array}$}} & -27.67 \\
\hline McFadden R-squared & 0.55 & & & 30.31 (prob. $=0.00)$ \\
\hline
\end{tabular}


The result also shows that the intensive external support is positive for charcoal supply. Probably the service of the external organization could have aware communities to consider socially disadvantaged groups. Interestingly this study little supports that the representatives of oppressive groups contribute to address own group interest in collective action. Similarly there was no significant influence of the participation of women and socially influential groups on charcoal distribution.

\section{Conclusion}

In principle, the Kami as a forest dependent oppressive group need, deserve and entitle to get special property right. However, this group has lost access to charcoal in many community forests after the introduction of CF programme. The Kami with the charcoal based livelihood have become further marginalised in many forest user groups. The right of the group has not been protected by the government. This study proved that the collective management abuses (restricting the people's access to the resource though they have the right to use it) the powerless people of the society and further oppressed. This is a violation of the UN Rio Summit commitment to protect the rights of dominated, occupational and oppressed groups. This study also identified that indigenous knowledge valuable for sustainable development of mountains has been threatened by the institutional changes.

This study explained that the probability of the distribution of charcoal is less likely in large groups and small size of forests. The negative relation with household size and positive relationship with forestland size for the probability of distributing charcoal result indicate a pessimistic future prospect for Kami. It is because the size of group increases as the population grows so the probability of access decreases. Most of the forests are smaller in size and the size of the forests cannot increase. As a policy implication, their access to charcoal from community forests could be secured only if their special property rights are granted. The significant negative sign for group size, and non-significant results for oppressed group representative and leadership type, indicate the collective complexity of the resource management determines oppressed groups' access to collectively managed resource.

This study indicates the charcoal distribution is less likely in low intensive external support districts. In
Nepal, many districts have no intensive support. If the result coincides with the representative of other districts, then the community forestry programme has victimised many Kami families in the country. Group meeting is also a factor determining charcoal distribution. However, the community meeting frequencies are little changed by policy intervention in long term.

The future of the Kami's access to their livelihood supporting resource is uncertain. Other measures could have little effective to address this life threatening case. Those Kami currently getting the charcoal could also loose the access in future unless their property rights are well defined and specified. Special policy enforcement instruments or compliances require protecting and increasing common property access to special need groups such as Kami.

\section{References}

Adhikari, B., Falco1, S. and Lovett, J. 2004. Household characteristics and forest dependency: evidence from common property forest management in Nepal, Ecological Economics, 48 (2): 245-257.

Agrawal, A. 2002. Common Resources and Institutional Sustainability. In Drama of the Commons. Ostrom, E. (Editor). Washington, DC, USA: National Academies Press, Pp41-85.

Agrawal, B. 2001. Participatory Exclusion, Community Forestry, and Gender: An Analysis of South Asia and a Conceptual Framework. World Development 29 (10): 1623-48.

Bista, D., 1991. Fatalism and development: Nepal's struggle for modernization. Orient Longman, Calcutta

Bromley D.W. 1989. Economic Interests and Institutions. Basil Blackwell Oxford

Challen, R. 2000. Institutions, Transaction Costs and environment Policy. Institution Reform for Water Resource. Cheltanham, Edward Elgar.

Dobson, A. 1998. Justice and the Environment. Oxford University Press.

Duncan, C. 1996. Understanding Persistent Poverty: Social Class Context in Rural Communities. Rural Sociology. 61(1): 103-124.

Ghate, R., 2003. Ensuring Collective Action inParticipatory Forest Management. 
SANDEE Working Paper No 3-03. Katmandu, Nepal

Graner, E 1997. The Political Ecology of Community Forestry in Nepal. Saarbruken: Verlag fur Entwickungspolitik

Hobley, M. 1996. Participatory forestry: The process of Change in India and Nepal. Rural Development Forestry Network, Overseas Development Institute London

Janvry A., McCarthy, N. and Sadoulet, Elisabeth. 1998. Endogenous provision and appropriation in the commons. American Journal of Agricultural Economics: 80(3): 658-665

Kabeer, N. and Subrahmanian R. 1996. Institutions, Relations and Outcomes: Frameworks and Tools for Gender Aware Planning. IDS Paper 357, IDS, Brighton. England.

Kothari, U. 2003. Staying put and staying poor? Journal of International Development. 15(5): 645-659

Long, J.S. 1997. Regression models for categorical and limited dependent variables. Advanced quantitative techniques in the social sciences. Thousand Oaks : Sage Publications..

Mahat, T., Griffin, D. and Shepherd, K. 1987. Human impacts on some forests of middle hills of Nepal. Part3. Forests in the subsistence economic of
Sindhupalchok and Kavrepalanchok. Mountain research and Development. 7(1): 53-70

NPC. 2003. The Tenth Plan 2002-2007 (Poverty Reduction Strategy Paper-Summary). His Majesty's Government. National Planning Commission, Kathmandu, Nepal.

Olson, M., 1965. The Logic of Collective Action. Harward University Press, Cambridge.

Rawls, J. 1971. A Theory of Social Justice. Oxford: Oxford Clarendon Press.

Ribot, J. and Peluso, N., 2003. A theory of access. Rural Sociology. 68 (2), 153-172

Vedeld, T. 2000. Village Politics: Heterogeneity, Leadership and Collective Action. Journal of Development Studies. 36(5): 105-134

Vogt, R. 1998. Whose Property? The Deepening Conflict between Private Property and Democracy in Canada. Toronto: University of Toronto Press.

Weimer, D. 1997. The political economy of the property rights. In The Political Economy of the Property Rights. (ed) David L. Weimer. Cambridge University Press, New York.

Young, I. 1990. Justice and the Politics of Difference. New Jersey: Princeton University Press. 